\title{
A lógica da polícia militar do Distrito Federal na construção do suspeito
}

Gilvan Gomes da Silva

Curso: Mestrado em Sociologia

Data da defesa: 21 de agosto de 2009

Orientadora: Prof ${ }^{\mathrm{a}} \mathrm{Dr}^{\mathrm{a}}$ Analia Laura Soria Batista

\section{Resumo}

As abordagens policiais constituem interações sociais rotineiras entre o cidadão e o policial, que podem traduzir, de certa forma, as relações complexas entre a Sociedade Civil e o Estado. Este trabalho discorre sobre os fatores que influenciam no processo 
cognitivo de construção da suspeição policial pelos policiais militares do Distrito Federal.

Pretendeu-se identificar quais os conhecimentos "oficiais" (aqueles que são transmitidos nas escolas e academias de formação e de especialização da PMDF) referentes às abordagens policiais militares no Distrito Federal. Especificamente, os conhecimentos de policiamento ordinário e policiamento especializado; quais os saberes construídos pelos (as) policiais militares acerca das abordagens a indivíduos suspeitos, a indivíduos que cometeram alguma ação suspeita e/ou a indivíduos em uma situação suspeita; as percepções socialmente construídas de gênero, étnicas ou raciais, de classe, de localizações geográficas ou quaisquer outros fatores influenciam na categorização de indivíduos ou ações suspeitos; a racionalidade da ação de busca do policial militar e se esta ação tem caráter legal e/ou legítimo; analisar os crimes que são focados para serem combatidos e prevenidos e sua relação com os suspeitos, se há uma escala de valor que tolere um crime mais que outros e entender quais as conseqüências de cada ação policial na busca pessoal ou veicular com os suspeitos.

A pesquisa utilizou dados de observação participante das atividades policiais realizada em duas unidades policiais da PMDF em um período de dois anos, com a participação de cursos de formação e especialização policial; análise de manuais, portarias, diretrizes policiais e dados disponibilizados pela Secretaria de Estado de Segurança do Distrito Federal.

A partir deste processo de análise, foi possível classificar as fontes que orientam as ações policiais com os indivíduos suspeitos, a ação suspeita e a situação suspeita. Os fatores que influenciam a construção da suspeição estão relacionados com o grau de igualdade jurídica, política, econômica, social e cultural de uma determinada sociedade.

Palavras-chave: polícia; suspeição; controles sociais. 